\title{
Social Status as a Predictor of Race and Gender Stereotypes in Late Childhood and Early Adolescence
}

\author{
Stephanie J. Rowley, University of Michigan, Beth Kurtz-Costes, \\ Rashmita Mistry and Laura Feagans, Center for Developmental \\ Science and University of North Carolina
}

\begin{abstract}
We examined race and gender stereotypes in fourth-, sixth-and eighth-grade White and Black children. The participants reported their perceptions of the competence of Black, White, female and male children in academic domains, sports and music. In general, low-status groups (girls and Black children) did not endorse stereotypes that reflected negatively on their own group but were likely to report stereotypes that favored their social group. High-status groups (boys and Whites) endorsed most traditional stereotypes, whether negative or positive, for their social group. Where age differences appeared, older children were more likely than younger children to report traditional stereotypes and status effects were more pronounced. The results are discussed in terms of group enhancement and relationships between social stereotypes and self-views.
\end{abstract}

Keywords: racial stereotypes; gender stereotypes; academic stereotypes; social status

Stereotypes have been studied extensively, particularly with regard to their influence on the information processing and social cognition of adults (e.g., Miller, 1982; Ruble, Cohen \& Ruble, 2001; Steele, 1997). A growing body of literature has also shown the importance of stereotypes for the identity formation, concept development, decision making and moral reasoning of children and adolescents (e.g., Augoustinos \& Rosewarne, 2001; Bigler, Averhart \& Liben, 2003; Hirschfeld, 1996; Jacobs, 1991; Signorella, Bigler \& Liben, 1993; Weinraub, Clemens, Sockloff, Ethridge, Gracely \& Myers, 1984). The purpose of the present study was to investigate how differences in social status among race/gender groups relate to differing patterns of stereotype endorsement. In addition, we examined age differences in children's stereotypes. In the following discussion, we first briefly summarize issues related to the development of race and gender stereotypes. Next we discuss status theory and how academic, sports and music stereotypes might be expected to differ by race and sex. We conclude with a description of our research questions.

Correspondence should be addressed to Stephanie Rowley, Department of Psychology, 525 E. University, Ann Arbor, MI 48109-1109, USA. Email: srowley@umich.edu 


\section{The Development of Social Stereotypes}

Stereotypes are judgments on individuals based on their membership in a specific social group (Ruble et al., 2001). Children become aware of race and gender as social categories quite early. By 30 months of age children label themselves and others as male and female and show some limited knowledge of gender stereotypes, and by three years, children reliably categorize individuals according to race (Aboud, 1988; Fagot \& Leinbach, 1989; Ruble \& Martin, 1998; Weinraub et al., 1984). Across the childhood years, knowledge of these social categories becomes more detailed and more differentiated so that by middle childhood, children are able to distinguish among a wide variety of occupations, activities and attributes on the basis of gender cues (Ruble \& Martin, 1998). Research in race stereotypes has shown a similar developmental progression with increases in personal stereotypes and an awareness of the stereotypes of others as children proceed through middle childhood (Doyle \& Aboud, 1995; McKown $\&$ Weinstein, 2003). Although considerable bodies of research have addressed children's awareness of gender and race as social categories, a relatively small part of this work has examined children's beliefs regarding sex and race differences in competence in the domains of academic skills, sports and music abilities - domains that are an important part of the activities and self-views of children as they enter adolescence (Eccles, Wigfield, Flanagan, Miller, Reuman \& Yee, 1989).

In spite of the paucity of work examining children's race and gender stereotypes in those domains, a substantial body of research has shown that gender differences appear in self-perceptions of skill by middle childhood. This research has shown that boys tend to overestimate their performance across the board and that both boys and girls report self-perceptions in line with traditional stereotypes (i.e., girls report greater selfcompetence in verbal domains whereas boys report greater self-competence in maths and science) (Eccles, Wigfield, Harold \& Blumenfeld, 1993; Jacobs, Lanza, Osgood, Eccles \& Wigfield, 2002; Wigfield \& Eccles, 1994; Wigfield, Eccles, Harold, Blumenfeld, Arbreton \& Freedman-Doan, 1997). Elementary-aged girls' and boys' selfperceptions of sports and music abilities are also parallel to societal stereotypes. Girls believe that they are better in music and boys view themselves as better at sports (Csizma, Wittig \& Schurr, 1988; Jacobs et al., 2002; Wigfield et al., 1997). Researchers have not yet substantiated whether or not differences in individuals' perceptions of self-competence reflect beliefs regarding sex differences in ability. For example, are girls who report that they are not good at maths and are boys who report high maths competence also likely to report that boys are better at maths than girls?

Although children's self-perceptions reflect traditional stereotypes regarding sex differences in performance across domains, their actual performance during middle childhood and early adolescence does not consistently support those stereotypes. For instance, research has shown that girls tend to do as well as or better than boys in maths until high school (Leahy \& Guo, 2001). Nonetheless, there is a fair amount of evidence that within our culture, maths is viewed as a 'male' domain. Firstly, parents and teachers see boys as more competent in maths and science than girls, often attributing boys' maths success to ability and girls' maths success to effort (Bleeker \& Jacobs, 2004; Parsons, Adler \& Kaczala, 1982; Tiedemann, 2000). Secondly, beginning at the secondary level, boys take more advanced maths courses than girls and outperform girls in some areas of maths and science (Bacharach, Baumeister \& Furr, 2003; Farmer, Wardrop, Anderson \& Risinger, 1995; Leahy \& Guo, 2001). Thirdly, women continue to be underrepresented in high status professions that rely heavily on maths such as 
engineering and information technology and in the highest status science professions (National Center for Education Statistics, 2002; National Science Foundation, 2000). The present study will be able to address the extent to which girls and boys report stereotypes in line with common societal views vs. the reality of girls' relatively strong performance during the period of study (i.e., late elementary school and middle school). We will also examine whether or not and how gender stereotypes differ between those in late childhood and early adolescence (see Alfieri, Ruble \& Higgins, 1996; Galambos, Almeida \& Petersen, 1990 for a discussion).

Within the domain of race, a persistent stereotype in the USA has been that Blacks are not as smart and do not do as well in school as their White (and Asian-American) counterparts (Bobo, 2001; Steele, 1997; Swim \& Stangor, 1998). In addition, it is widely believed that Blacks possess a natural talent in the areas of music and especially, sports (Grant, 1985; Lee \& Browne, 1995; Sailes, 1991). In a recent investigation of the development of stereotype consciousness, McKown and Weinstein (2003) found an increasing awareness of stereotypes regarding race differences in academic ability from the ages of six to ten, and children of stigmatized ethnic groups (i.e., Blacks and Latinos) at all ages were more aware of broadly held social stereotypes than those of non-stigmatized (i.e., Whites, Asian-Americans) ethnic groups. Unfortunately, little research examining the personal endorsement of race academic stereotypes has spanned the entry to adolescence.

\section{Social Status and Stereotype Endorsement}

There is strong evidence that people tend to be biased in favor of the social groups to which they belong (Bigler, Brown \& Markell, 2001; Crocker \& Major, 1989; Tajfel \& Billig, 1974). Social psychologists have long reported that both adults and children quickly and easily develop in-group biases even when the groups are created arbitrarily (Nesdale \& Flesser, 2001; Tajfel \& Billig, 1974). These in-group biases typically play a self-enhancing role for group members. However, manipulations of the status of particular groups show that members of low-status groups do not always hold in-group biases (Bigler et al., 2001). In a study by Bigler et al. (2001), elementary school children were randomly assigned to different groups. A colored t-shirt worn during school hours denoted group membership. Children were subtly primed over time to be aware of the greater status of one group over the other. As in research by Tajfel (1970), children from high status groups showed an in-group bias. But children from low status groups did not (Bigler et al., 2001). In particular, high status children were more likely than low status children to state that they wanted to continue to be in the same t-shirt group. Low status group members tended to be egalitarian in domains where their group was negatively stereotyped. That is, they reported neither in-group nor out-group preferences (Bigler et al., 2001). This egalitarian stance may reflect efforts to protect self-esteem by remaining neutral in areas where one's own social group is disparaged.

Much of the social psychology literature that has informed our understanding of social status and in-group/out-group bias comprises laboratory studies where group membership was experimentally manipulated, and/or where low status was synonymous with a negative stereotype (e.g., Tajfel, 1970; Tajfel \& Billig, 1974). In our society, however, race and gender groups differ significantly in terms of their status and power, and groups of low status are stereotyped in some positive ways (e.g., girls are talented in verbal domains; Blacks are talented in sports). 
These prior laboratory studies lead to the prediction that low status groups, in contrast to high status groups, might not endorse stereotypes that reflect negatively on their own social group but would endorse positive stereotypes of their own group. For instance, Black children may strongly endorse social stereotypes regarding sports that favor Blacks over Whites and may fail to report academic stereotypes that put Blacks at a disadvantage. With regard to gender stereotypes, girls may emphasize the belief that girls are better than boys in reading and writing as a way to compensate for stereotypes that reflect negatively on the performance of girls in math and science. Because of the relatively higher status enjoyed by high status group members, it might be less important for them to self-enhance by not endorsing stereotypes that reflect negatively on their social group. Most prior studies of low status groups only evaluated these groups on negative attributes. In this study, we assessed whether members of disparaged or low status groups (i.e., girls, Blacks) would endorse negative and positive stereotypes of their own groups or would simply report no differences.

The present study taps into deeply entrenched societal stereotypes regarding race and gender in the USA. We chose to examine academic, sports and music abilities for two reasons. Firstly, these skills are highly salient to young adolescents given the percentage of their time spent in school and extracurricular activities and the influence of academic, music and sports activities on adolescent friendship choices. Secondly, the project was designed to assess the endorsement of positive as well as negative stereotypes; thus, an examination of these domains enabled us to separate status from stereotype valence. Few studies have examined these theoretical questions spanning the entry to adolescence - a time of substantial increases in social knowledge and of the increasing stratification of ability groups as children move into middle school (Anderman \& Midgley, 1997). The focus on ability in middle school, coupled with the increasing range of academic achievement, may serve to amplify societal stereotypes regarding race and gender differences in academic ability. Views regarding group competence in sports and music may also become more traditional as participation in activities such as sports teams and bands in middle school becomes more competitive and exclusive.

An additional unexplored question relates to the interaction between race and gender. Although Whites and boys typically have a higher status in the classroom than Blacks and girls, academic stereotypes of Black boys tend to be less positive than those of Black girls (Graham, Taylor \& Hudley, 1998; Hudley \& Graham, 2001; Sidanius \& Pratto, 1999; Sidanius \& Veniegas, 2000). In a study of academic stereotypes in an ethnically diverse sample of seventh and eighth graders, Hudley and Graham (2001) found that boys and girls of all ethnic backgrounds viewed Black and Latino boys as least likely to be engaged in the classroom. According to status theory of stereotyping, if Black boys are of lowest status, they should be the most egalitarian in their academic stereotypes and would report greater male and race advantages in sports than other groups do. On the other hand, some theorists suggest that Black girls suffer from double jeopardy (Beale, 1970) from being at once girls and Black. If double jeopardy theory holds, Black girls should be less likely than Black boys to endorse the stereotype that boys are better in maths/science, and they may be more likely to report positive stereotypes such as a female advantage in literacy skills.

\section{Goals of This Study}

The present study examines race and gender stereotypes regarding academic, sports and music skills in fourth-, sixth- and eighth-grade White and Black children in order 


\section{Stephanie J. Rowley et al.}

to determine whether or not stereotype endorsement varies according to the social status of the individual. We expected that members of low status groups (girls, Blacks) would report stronger stereotypes than high status groups in domains where their group is positively represented and that they would report no group differences in domains where their social group is negatively stereotyped. High status individuals (boys, Whites), in contrast, were expected to report traditional stereotypes but to be less influenced by in-group bias, thereby reporting weaker stereotypes that favored their own group. In addition, we examined whether or not age played a role in stereotype reports and in the effect of group status on stereotype endorsement. We examined these age groups to capture children's stereotype beliefs on both sides of the transition to middle school, a time of rapid cognitive, social and physical change.

\section{Method}

\section{Participants}

The participants were 448 children in a cross-sectional investigation of children's social stereotypes conducted in the southeastern region of the USA. Because we were interested in examining how Black children compared their group to Whites and how White children compared their group to Blacks, only the data of children who indicated that they were European American/White $(n=209)$ or African-American/Black $(\mathrm{n}=239)$ were included in the analyses reported here (see Table 1 for breakdowns by race, gender and grade). Children of other ethnicities, including 37 Hispanics, nine Asian-Americans, four Native Americans and seven children of mixed ethnicity were dropped from this set of analyses. To determine race/ethnicity, we asked the participants to circle the label that best reflected their racial or ethnic group. These included the categories European American/White, African-American/Black, Hispanic/Latino, Native American, Asian-American/Pacific Islander and Other. Children who chose the 'Other' category were asked to write their ethnicity in the space provided. The participants who circled two ethnic groups $(n=7)$ were classified as biracial and were excluded from the present analyses.

The sample of 448 children comprised of 157 fourth graders ( 74 boys, 83 girls), 137 sixth graders ( 57 boys, 80 girls) and 154 eighth graders ( 55 boys, 99 girls). The fourth graders were from five elementary schools and one K-8 school. The sixth and eighth graders were from one K-8 school and four middle schools. Black children represented between 18 percent and 84 percent of the school population in the participating

Table 1. Numbers of Participating Children Within Each Race, Gender and Grade

\begin{tabular}{ccccr}
\hline & Fourth Grade & Sixth Grade & Eighth Grade & Total \\
\hline White & & & & \\
Boys & 33 & 29 & 32 & 94 \\
Girls & 27 & 33 & 55 & 115 \\
Black & & & & \\
Boys & 41 & 28 & 44 & 92 \\
Girls & 56 & 47 & 47 \\
\hline
\end{tabular}


schools. The mean ages were 9.6 years for the fourth graders $(S D=.74), 11.6$ years for the sixth graders $(S D=.67)$ and 13.5 years for the eighth graders $(S D=.57)$.

\section{Procedure}

Written parental-informed consent was a prerequisite for study participation. Selfreport questionnaires were administered to groups of two to 15 children on school premises. The research assistants read a prepared script giving general directions and instructing children to respond to each item. For most of these sessions, at least one White and one Black research assistant were present. For sessions that involved children of only one ethnic group, the ethnicity of interviewers sometimes matched the ethnicity of the participants. Most interviews of the fourth graders were conducted by female research assistants. Because we learned that it was easier to recruit middle school boys for the project if male research assistants were present, many of the middle school interviews were conducted by one female and one male research assistant. Questionnaires were completed in a single session. Each participating child received a small gift (e.g., stress ball, key chain, flashlight) at the end of the session.

\section{Measures}

Perceptions of Group Competence. Visual analog scales (VAS) - a 100-millimeter line for each item with descriptive anchors at each end-were created to capture how children believed boys, girls, Blacks, Whites, and rich and poor children perform in a variety of areas such as sports, reading and maths. VAS are often used in cases where researchers want to minimize constraints on participants' responses, such as in describing the pain they are experiencing. It is likely that testing group competence beliefs using formats such as Likert scores with only a few possible responses may increase social desirability effects because respondents may feel uncomfortable assigning a group the lowest rating. A VAS format allows participants to give a group a relatively low rating without choosing the lowest category. For each item, the participants placed a mark on the 100-millimeter line to indicate how capable they felt that particular group of children was within a specific domain. For example, the item 'I think that in science boys do this well' was followed by a scale with 'not good at all' on the far left (zero millimeters) and 'very good' on the right (100 millimeters). Separate items were used to assess maths, science, reading, writing, music, sports, school grades and smartness for each of the six social groups. The children rated each social group (e.g., girls) on all eight items before proceeding to the next social group. The social groups were arranged in three different sequences in order to control for response bias. In addition, the two members of each social category were never adjacent to one another in the protocol (e.g., 'boys' was not adjacent to 'girls'). Perceived group competence scores represented how far in millimeters along the 100-millimeter line a child had marked, with the lower scores representing lower competence ratings. All the children were given two practice questions (cooking, drawing) to ensure that they understood the visual analog scales. The children's competence judgments of rich and poor children are not included in this report.

Stereotype Scores. Exploratory factor analyses were used to determine whether or not items could be aggregated. Each social category (i.e., race, gender) was examined separately. The results of these factor analyses as well as the previous literature 
on the nature of race and gender stereotypes led us to create different composite stereotype scores for gender and race. In each case, items that strongly factored together (loadings were above .70 in all cases) were averaged to create a broader domain. For gender, the categories were maths/science, reading/writing, sports and music. For race, the categories were academics (maths, science, reading; writing was excluded because this item emerged as a unique factor in the race analyses), sports and music. Although smartness and grades were factored with all academic domains, these items were omitted to increase the interpretability of the subscales. We computed group competence scores (e.g., girls' reading/writing competence) for each domain and social group by averaging the appropriate scores. Factor structures were similar across race, gender and age groups. One exception was that the younger participants were less differentiated across academic domains than the older participants were. For instance, maths/science and reading/writing gender ratings tended to overlap more for younger children. Thus, we used the more differentiated solution of older children in the gender competence analyses.

\section{Results}

\section{Preliminary Analyses}

Before conducting the major analyses, we examined the effects of the presentation order of social groups (i.e., girls, Blacks, etc.) and school racial composition on competence ratings. One-way ANOVAs using the three questionnaire orders as the factor were used to test for the effect of social group presentation order on responses. The presentation order was unrelated to race competence scores; however, order affected all of the gender outcomes except estimates of girls' music ability and boys' sports abilities. It appears that this effect was primarily due to the fact that boys were disproportionately represented in the group that filled out Form 2 (based on a chisquare analysis of gender and form). Nevertheless, we controlled for order in all analyses on gender competence scores reported below.

In order to determine whether or not school race composition was related to competence scores the schools were grouped into one of three racial composition levels based on the percentage of African-American students at the school $(1=$ low, from 0 to 30 percent; 2 = medium, from 30 to 70 percent; 3 = high, from 70 to 100 percent). This resulted in grouping two schools in the low group (representing 53 students), seven schools in the medium group (representing 319 students) and five schools in the high group (representing 76 students). The relationship between the school racial composition and competence scores was analyzed using one-way ANOVAs. Gender competence ratings were unrelated to the school racial composition. However, each race group competence score except estimates of Blacks' sports abilities differed according to the school racial composition. In all cases, students at schools with a higher percentage of Blacks reported higher estimates of Blacks' abilities and lower estimates of Whites' abilities. Therefore, we controlled for school race composition in all analyses involving race stereotypes.

In order to test our hypotheses regarding social status and stereotypes we performed a series of repeated measures ANOVAs examining grade, sex and race differences in reports of group competence by social category. In each of these analyses, grade, sex and race served as between-subjects variables, and the group competence scores described above were within-subjects variables. The main effect of order was also 
estimated in the gender stereotypes analyses, and school race composition was included in race stereotypes analyses. Analyses were conducted separately for gender and race stereotypes.

\section{Gender Stereotypes}

To examine group differences in gender stereotypes, a series of $2(\operatorname{sex}) \times$ 2 (race) $\times 3$ (grade) $\times 3$ (order) repeated measures ANOVAs was run. Estimates of girls' vs. boys' competence (group) served as within-subjects factors for each domain (i.e., maths/science, reading/writing, music, sports). If social status influences stereotypes in the hypothesized manner, an interaction between group and sex should emerge, with girls reporting that girls are more competent in reading/writing and music than boys. Boys, not girls, were expected to report traditional maths/science and sports stereotypes (i.e., male competence scores higher than female). In addition, a race $\times$ sex $\times$ group interaction was explored to determine if Black boys responded as a high status (male) or low status (Black) group.

Gender Maths/Science Differences. In the analysis on maths/science scores, the main effect of group was significant, $F(1,431)=36.85, p<.001$. Overall, girls $(M=72.07$, $S D=19.62)$ were viewed as more competent in maths/science than boys were $(M=63.31, S D=21.30)$. The interaction between group and sex was also significant, $F(1,431)=84.60, p<.001 \quad$ (see Figure 1) but was qualified by significant group $\times$ sex $\times$ grade and group $\times \operatorname{sex} \times$ race interactions, $F(2,431)=6.80$ and 19.77 , respectively, $p s<.001$. The group $\times$ sex $\times$ grade interaction suggested that whereas fourth-grade boys rated boys as better than girls in maths/science competence
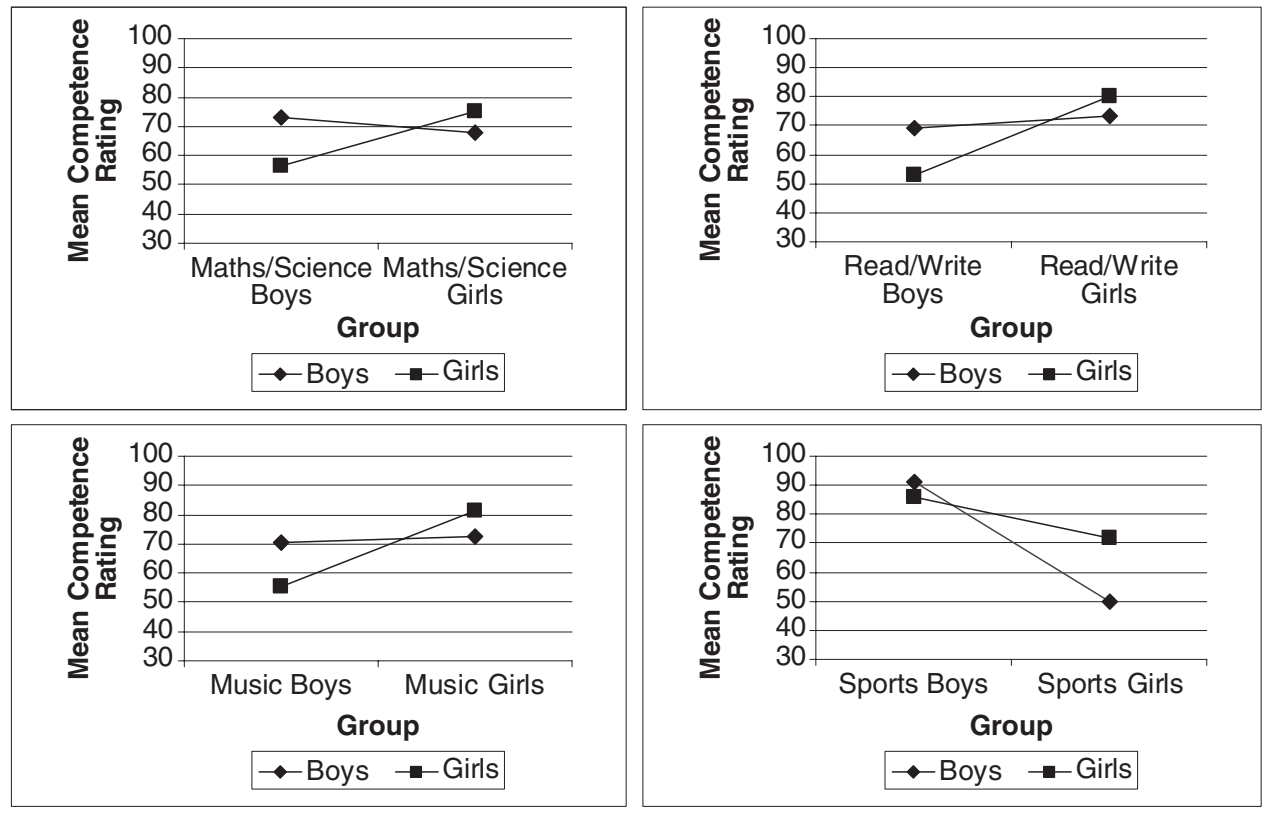

Figure 1. Mean Gender Group Competence Ratings by Gender of Participant for all Domains. 


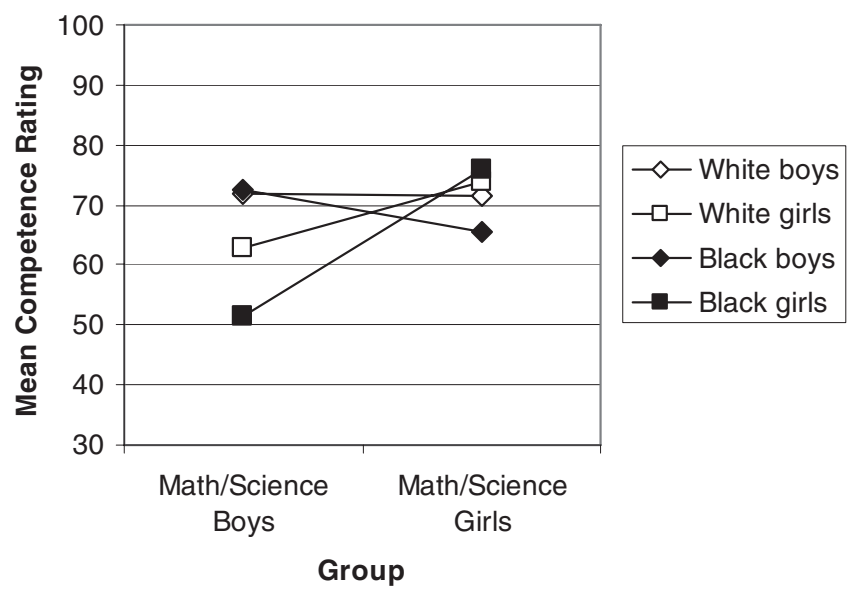

Figure 2. Mean Gender Group Math/Science Competence Ratings by Race and Gender.

$\left(M_{b}=77.38, S D=17.98 ; M_{g}=64.69, S D=21.11\right)$, sixth $\left(M_{b}=69.49, S D=20.06\right.$; $\left.M_{g}=70.76, S D=23.40\right)$ and eighth graders $\left(M_{b}=71.09, S D=18.18 ; M_{g}=68.84\right.$, $S D=18.76)$ were more egalitarian. Girls, on the other hand, reported advantages to girls in fourth $\left(M_{g}=78.31, S D=19.12 ; M_{b}=53.37, S D=20.19\right)$, sixth $\left(M_{g}=71.55\right.$, $\left.S D=16.67 ; M_{b}=56.19, S D=19.28\right)$ and eighth grades $\left(M_{g}=75.20, S D=17.26\right.$; $\left.M_{b}=59.26, S D=20.75\right)$. Note that this advantage diminishes during the middle school grades, as girls' ratings of girls' competence is lower in middle school than in fourth grade whereas their ratings of boys' competence are climbing. The group $\times \operatorname{sex} \times$ race interaction suggested that White girls viewed boys as relatively more competent $(M=62.76, S D=16.47)$ than did Black girls $(M=51.17$, $S D=21.44)$. In contrast, Black boys viewed boys as better than girls in maths/science $\left(M_{b}=73.17, S D=20.81 ; M_{g}=65.20, S D=24.82\right)$, and White boys were egalitarian $\left(M_{b}=72.24, S D=17.01 ; M_{g}=70.55 S D=16.83\right)$. Figure 2 shows stereotype scores associated with this interaction.

Gender Reading/Writing Differences. A similar ANOVA was used to examine perceived sex differences in reading/writing ability. The main effect of group suggested that this sample, overall, viewed girls $(M=77.44, S D=19.25)$ as better than boys $(M=59.57, S D=22.22)$ in reading and writing skills, $F(1,430)=168.04, p<.001$. The group $\times$ grade interaction was significant, $F(1,430)=7.98, p<.001$. This interaction suggested that although girls were rated as better than boys in reading/writing at each grade, the magnitude of the difference increased from fourth $\left(M_{g}=74.04\right.$, $\left.S D=21.31 ; M_{b}=63.51, S D=21.20\right)$ to sixth $\left(M_{g}=77.26, S D=20.15 ; M_{b}=56.90\right.$, $S D=22.70)$ and eighth $\left(M_{g}=80.73, S D=15.40 ; M_{b}=58.01 ; 22.39\right)$ grades. The interaction of group $\times$ sex was also significant, $F(1,430)=66.08, p<.001$ (see Figure 1) but was qualified by a group $\times \operatorname{sex} \times$ race interaction, $F(1,430)=9.56, p<.01$. Whereas Black boys reported egalitarian views of gender differences in reading/ writing ability $\left(M_{g}=71.90, S D=24.24 ; M_{b}=71.05, S D=21.39\right)$, White boys reported that girls were better than boys $\left(M_{g}=75.51, S D=18.98 ; M_{b}=66.64, S D=19.95\right)$. White $\left(M_{g}=80.12, S D=14.23 ; M_{b}=55.76, S D=19.00\right)$ and Black girls $\left(M_{g}=80.19\right.$, $\left.S D=18.58 ; M_{b}=50.32, S D=21.84\right)$ both reported a larger advantage for girls than 


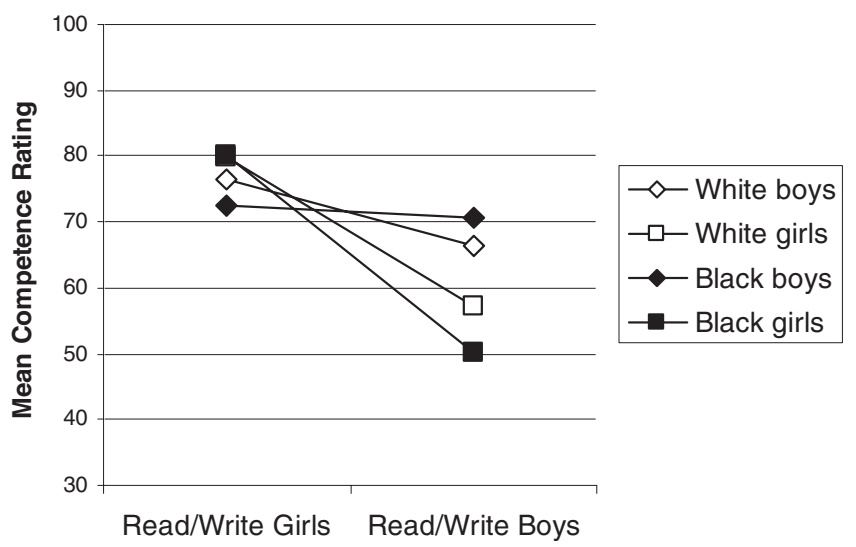

Group

Figure 3. Mean Gender Group Reading/Writing Competence Ratings by Race and Gender.

did White boys. This difference was larger for Black girls than for White girls (see Figure 3). No other interactions were significant.

Gender Music Differences. As with the reading/writing analysis, an ANOVA on music competence scores showed an overall effect of group, $F(1,428)=84.59, p<.001$ that was qualified by several higher order interactions. Students generally viewed girls $(M=77.82, S D=22.31)$ as better in music than boys $(M=61.60, S D=27.21)$. Interactions of group $\times$ sex (see Figure 1) and group $\times$ race, $F(1,428)=56.36$ and 6.68 , respectively, $p<.001$, are better understood in terms of the higher level interaction of group $\times \operatorname{sex} \times$ race, $F(2,428)=6.11, p<.05$. Although Black and White girls similarly viewed girls as better in music than boys (Black: $M_{g}=81.65, S D=17.54 ; M_{b}=56.03$, $S D=24.29$; White: $\left.M_{g}=80.84, S D=16.76 ; M_{b}=54.77, S D=24.80\right)$, boys showed less traditional stereotypes. Specifically, Black boys reported an advantage of boys over girls in music $\left(M_{b}=76.62, S D=28.57 ; M_{g}=69.98, S D=27.14\right)$, and the difference between estimates of boys' and girls' abilities were smaller for White boys $\left(M_{b}=64.92, S D=24.63 ; M_{g}=74.97, S D=21.22\right)$ than for either group of girls.

Gender Sports Differences. In analyses on sports scores, the main effect of group suggested that boys $(M=88.14, S D=18.25)$ are viewed as more competent in sports than girls $(M=62.69, S D=29.80), F(1,428)=272.81, p<.001$. Group $\times$ sex $($ see Figure 1) and group $\times$ race interactions were both significant, $F(1,428)=67.23$ and $8.16, p<.001$ and .01 , respectively. The group $\times$ sex interaction reflects the fact that boys rate boys as much better in sports than girls $\left(M_{b}=91.06, S D=14.36 ; M_{g}=49.72\right.$, $S D=31.99)$ whereas girls report a smaller advantage to boys $\left(M_{b}=86.07, S D=20.33\right.$; $\left.M_{g}=71.85, S D=24.34\right)$. Note that much of this effect is owing to boys' low rating of girls' abilities in sports. The group $\times$ race effect showed that although Whites and Blacks rated boys as better in sports than girls, Blacks tended to rate girls less positively $\left(M_{b}=89.52, S D=18.25 ; M_{g}=57.19, S D=32.45\right)$ than Whites rated girls $\left(M_{b}=87.61, S D=15.81 M_{g}=64.84, S D=26.24\right)$.

In summary the analyses on gender stereotypes provided a confirming evidence for our hypotheses regarding status differences in stereotype reports. Girls - the low-status 
group - were relatively more likely to report stereotypes that favored themselves (i.e., music, reading/writing) and did not report a male advantage in maths/science. Analyses of reading/writing, maths/science and music scores all supported the view that for gender stereotypes, both Black boys and Black girls were more likely than their White counterparts to report stereotypes that favored their own gender and were less likely to report those that placed their gender at a disadvantage. Students' stereotypes regarding sports abilities differed from the other domains in that all groups endorsed a strong male advantage. This advantage was smaller for girls and larger for Blacks - a low-status group that is positively stereotyped in this domain.

\section{Race Stereotypes}

Next, we computed a similar set of repeated measures ANOVAs to examine race, sex and grade differences in perceptions of competence for Blacks and Whites. Again, race, sex and grade were entered as between-subjects factors, and competence ratings for Blacks and Whites within each domain were entered as the within-subjects factor, group. As our preliminary analyses indicated that order did not affect race-based competence ratings, we did not include that variable in these analyses. We did, however, include school racial composition as a covariate because of the relationship between this variable and the estimates across race. Our status hypotheses predicted that Blacks would be more likely than Whites to report traditional music and sports stereotypes and would be less likely to report traditional academic stereotypes.

Race Differences in Academics. A significant main effect of group, $F(1,435)=9.22$, $p<.01$, showed that these participants viewed Whites $(M=67.98, S D=17.28)$ as better than Blacks $(M=65.99, S D=19.52)$ in academic domains. In addition, two-way interactions between group and grade, $F(2,435)=9.44, p<.001$ and between group and race were significant, $F(1,435)=25.39, p<.001$ (Figure 4$)$. These two-way interactions were qualified by a three-way interaction between group, grade and race, $F$ $(2,435)=10.19, p<.001$ (see Figure 5). This interaction suggests that Black students have an in-group bias in fourth grade $\left(M_{W}=59.96, S D=19.38 ; M_{B}=\right.$ $74.42, S D=17.75)$ but view Whites as more academically competent than Blacks in sixth $\left(M_{W}=68.97, S D=19.42 ; M_{B}=63.97, S D=20.57\right)$ and eighth $\left(M_{W}=70.20\right.$, $\left.S D=15.48 ; M_{B}=67.46, S D=19.85\right)$ grades. White students favored Whites over Blacks in each grade (fourth: $M_{W}=71.46, S D=14.87 ; M_{B}=62.99, S D=20.63$; sixth: $M_{W}=69.24, S D=14.85 ; M_{B}=63.60, S D=15.84$; eighth: $M_{W}=69.59, S D=13.99$; $M_{B}=60.16, S D=18.74$ ) (see Figure 5).

Race Differences in Music. In analyses of music competence among Blacks and Whites, the main effect of group was non-significant, suggesting that this group of students did not generally perceive race differences in music competence. However, the group $\times$ grade interaction was significant, $F(2,432)=4.60, p<.05$, as was the group $\times$ race interaction, $F(1,432)=27.20, p<.001$. No higher order interactions were significant. The group $\times$ grade interaction showed that stereotypes are more traditional in later grades, with estimates of Whites' abilities in music relatively similar $\left(M_{4}=60.94, S D=18.45 ; M_{6}=62.41, S D=17.44 ; M_{8}=59.75, S D=15.48\right)$ and estimates of Blacks' abilities becoming stronger $\left(M_{4}=73.00, S D=18.45 ; M_{6}=74.09\right.$, $\left.S D=18.51 ; M_{8}=77.07, S D=19.52\right)$. The interaction of group and race showed that although youth of both races viewed Blacks as better than Whites in music, Black 

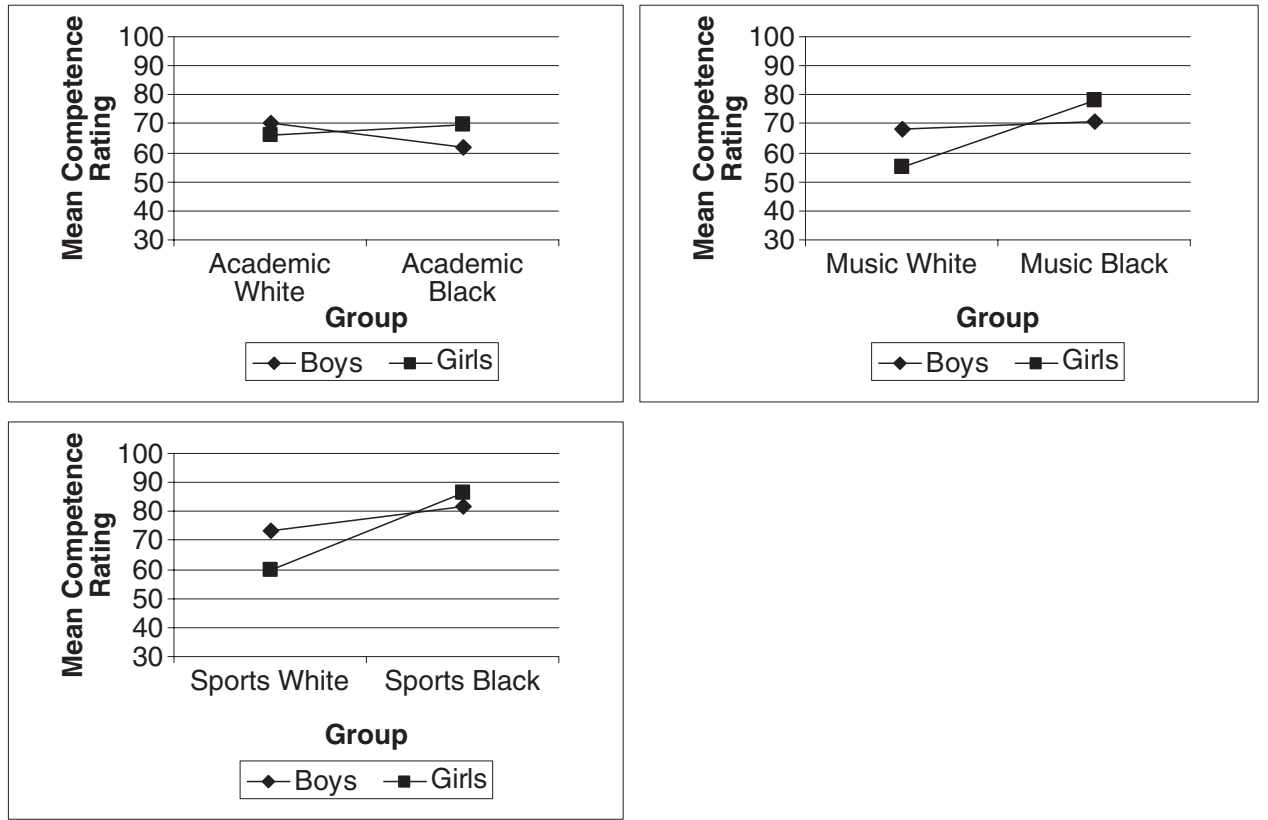

Figure 4. Mean Race Group Competence Ratings by Race of Participant for All Domains.

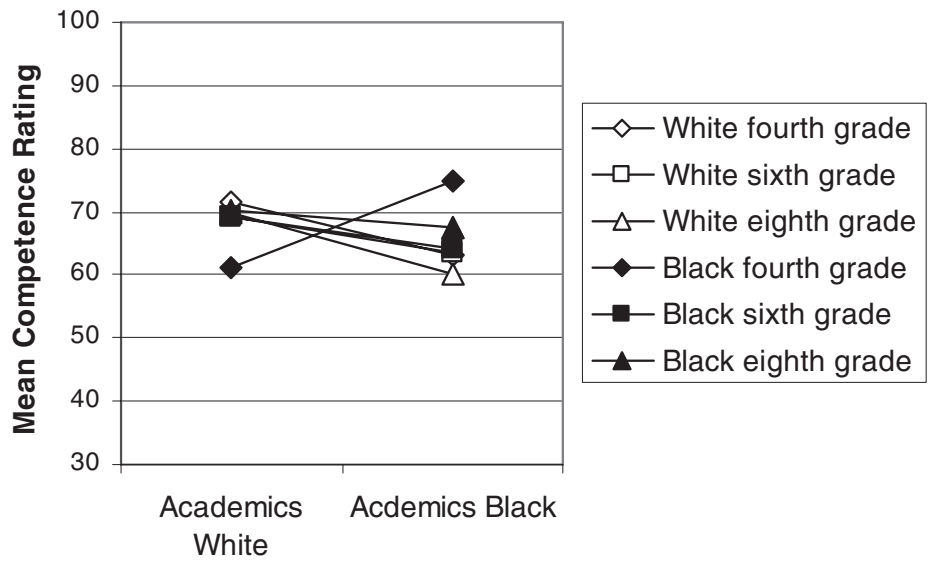

Group

Figure 5. Mean Group Academic Competence Ratings by Race and Grade.

students' stereotypes $\left(M_{W}=54.95, S D=19.24 ; M_{B}=77.90, S D=19.75\right)$ were stronger than those of Whites $\left(M_{W}=67.96, S D=14.46 ; M_{B}=70.93, S D=18.49\right)$.

Race Differences in Sports. A repeated measures ANOVA on sports competence scores yielded a significant main effect of group, $F(1,429)=9.68, p<.01$. Overall, students viewed Blacks as much better than Whites in sports $\left(M_{W}=66.10, S D=25.05\right.$; $\left.M_{B}=84.19, S D=19.03\right)$. Group $\times$ race and group $\times$ sex interactions were also 
significant, $F(1,429)=44.66$ and $8.82, p<.001$ and .01 , respectively. The group $\times$ race interaction showed that Whites' race stereotypes were traditional $\left(M_{W}=73.48, S D=18.86 ; M_{B}=81.65, S D=19.10\right)$ but not as strong as those of Blacks $\left(M_{W}=59.64, S D=27.84 ; M_{B}=86.16, S D=18.76\right)$. The group $\times$ sex interaction suggested that although both boys and girls reported greater sports competence for Blacks than Whites, this difference was larger for boys $\left(M_{W}=65.96, S D=27.83 ; M_{B}=88.08\right.$, $S D=16.52)$ than for girls $\left(M_{W}=66.10,22.93 ; M_{B}=81.23, S D=20.18\right)$. Note that girls' and boys' views of Whites' sports performance did not differ, but boys viewed Blacks as more competent than girls did.

In summary, stereotypes regarding race differences in academic, music and sports abilities for the most part confirmed hypotheses regarding status as a predictor. The low-status group-African-Americans-reported a stronger Black advantage in music and sports and reported less of a White advantage in academic work than did White students, the higher status group. In addition, interactions involving grade showed that youth in middle school were more traditional in their views than fourth graders, who were more likely to report an in-group bias regardless of status.

\section{Discussion}

The goal of this study was to examine Black and White children's academic, music and sports stereotypes regarding gender and race groups, with particular interest in the role of social status as a determinant of stereotype endorsement. We were also interested in how stereotypes differed across grades that span the transition to middle school and whether or not the role of status differed across age groups. In general, the results were consistent with our predictions regarding the role of social group status in stereotype endorsement. Where age differences emerged, older children were more likely than younger children to endorse traditional stereotypes and to show status effects whereas younger children were more likely to show an in-group bias that contradicted traditional stereotypes. In the following sections we discuss our results and their implications for theories of the development of stereotypes.

\section{Social Status and Stereotypes}

This study provides a fresh perspective on in-group bias and status theory in several ways. Firstly, we examined the real-world categories of sex and race-categories that are highly salient to individuals and play a strong role in shaping their identities. Secondly, we examined the endorsement of stereotypes that were both negative and positive for groups of varying social status, whereas most prior research has confounded status and valence, pairing negative attributes with low status and pairing positive attributes with high status. Thirdly, our design permitted us to examine interactions among race and gender subgroups, thereby testing whether or not the reports of Black girls vs. those of Black boys were most consistent with predictions of status theory. Finally, the inclusion of three age groups enabled us to determine if stereotypes and the influence of status on stereotypes are different for children before and after the transition to middle school.

With some exceptions, our results supported our predictions regarding status and stereotype endorsement. Low-status groups (girls and Blacks) did not endorse stereotypes that reflected negatively on their own group (with the exception of stereotypes regarding sports ability, discussed below). Girls did not report that boys excel in maths 
and science, and Black children reported small race differences in academic skills. Furthermore, low status groups more strongly endorsed commonly held positive stereotypes of their groups than did high status groups. For gender stereotypes, we found that low status individuals (girls) were more likely than high status individuals (boys) to report an in-group bias in all domains except sports. In the area of race stereotypes, the low status group (Black children) reported strong advantages for Blacks in sports and music. Thus, it was not the case that low status groups were simply more egalitarian than high status groups in their assessments.

We hypothesized that high status group members would be less likely than low status group members to self-enhance. White children - the high status groupendorsed traditional race stereotypes that Whites are stronger academically than Blacks; however, these stereotypes were much weaker than those of Black children's - the low status group-endorsement of sports stereotypes. Low status group members consistently endorsed positive stereotypes of their group and denied negative stereotypes. Girls reported that girls are quite a bit better in reading and writing and music than boys, and also reported a female advantage in maths/science. Black students, irrespective of gender, were likely to strongly endorse positive race stereotypes regarding music and sports abilities and reported no race differences in academics.

Several significant race by gender interactions showed the complexity of status theory. Black boys had egalitarian gender beliefs regarding reading/writing and reported a male advantage in maths/science and music. White boys, on the other hand, endorsed the traditional stereotype that girls are better than boys in reading/writing and music and were egalitarian in their views of maths/science. Black boys reported a greater male advantage in sports than any other group. Although these results seem to indicate that Black boys fit the profile of lowest status (Sidanius \& Pratto, 1999), some of our results are also consistent with the double jeopardy notion that Black girls deal with low race and gender status simultaneously. For example, the gap between boys' and girls' assessments of girls' greater reading/writing competence relative to boys was much larger for Blacks than for Whites. Thus, Black girls utilized a group enhancement strategy for both their female and their Black group memberships. It is also possible that these results are due to the fact that Black girls do outperform Black boys on average in verbal domains.

Taken as a whole, these results are consistent with the idea that members of high status groups are less likely than low status individuals to buffer their self-esteem by strongly endorsing positive stereotypes and by minimizing negative stereotypes regarding their social groups. The pattern of results suggests that race/gender groups were most likely evaluating members of their own racial group (i.e., White boys' assessments of boys were most likely of White boys). However, we do not have conclusive evidence of this as children were asked to evaluate only superordinate categories (e.g., Whites and boys). These results also underline the importance of studying gender in the context of race/ethnicity.

Although these results support status theory, it is not the case that there was no evidence of in-group bias. In every case, students rated their own groups' competence more highly than did members of the out-group. For example, although girls rated boys as better in sports, girls' ratings of the sports abilities of girls were higher than boys' ratings of girls. Our results indicate that all groups engage in some self-enhancement, but not always to the point where they rate their own group as better than the group that society views as more competent. 


\section{Gender, Race and Maths}

Our findings that on average, students reported a female advantage in maths and science are seemingly in contradiction with research showing that boys report higher self-competence than girls in maths and science. These reports may reflect the fact that, especially in the early grades, girls either outperform boys in maths and science or perform at the same level (Campbell, Hombo \& Mazzeo, 2000; Frome \& Eccles, 1998; Leahy \& Guo, 2001) or the prevalence of interventions aimed at increasing girls' performance in maths and science. On the other hand, these results may reflect the importance of studying gender stereotypes within the context of race. Although White boys - a high-status group - were egalitarian in their reports of sex differences in maths and science skills, Black boys reported that boys are better than girls in maths and science. The most pronounced female maths/science advantage was reported by Black girls, whose reports may have been influenced by their relatively low status or by virtue of their actual excellent maths/science achievement compared to Black boys.

\section{Age Differences in Race and Gender Stereotypes}

Our results showed some interesting age differences in stereotype endorsement. Age differences were significant for gender read/write and race academic stereotypes, as well as for the racial music stereotypes. Stereotypes were generally more traditional for children in later grades. For instance, girls viewed girls as superior in reading and writing at all grades, but the advantage given to girls was larger in the sixth and eighth grades than in the fourth. Similarly, Blacks were viewed as better in music at all grades, but more so during the middle school grades.

We also found that interactions between age and sex and race suggest that social groups vary in the patterning of age differences. In general, these interactions support a strengthening of the status effect with age. For instance, whereas Blacks show an in-group bias in academic stereotypes in fourth grade, they report no difference between groups in the sixth and eighth grades. Whites, on the other hand, demonstrate a larger in-group bias from the fourth to sixth and eighth grades.

Although we did find age differences in gender maths/science stereotypes, they varied by sex: whereas middle school boys' stereotype reports favored girls more than fourth grade boys' reports, middle school girls reported less advantage for girls in maths/science than fourth grade girls. It is possible that the superior performance of girls in maths/science during these grades shaped these stereotypes. Meanwhile, middle school girls' stereotypes were more in line with those traditionally reported by parents and teachers than those of their fourth-grade counterparts (Bleeker \& Jacobs, 2004; Parsons et al., 1982; Tiedemann, 2000). It is likely that stereotype reports of both genders may shift to favor boys in high school because it is during high school that boys begin to outperform girls in some areas of maths and take more advanced maths courses than girls (Leahy \& Guo, 2001).

\section{Limitations and Questions for Future Research}

This study adds to the literature on stereotyping in that we used direct assessments of children's beliefs regarding the abilities of different groups rather than using implicit assessment techniques. However, this design raises the possibility of effects of social desirability and political correctness. Indeed, even White students' reports of sensitive 
issues such as Black-White differences in academic achievement were of much smaller magnitude than boys' reports of the more socially acceptable stereotypes of gender differences in reading and writing. Overall, students' reports of group differences in music/sports abilities — an area that has relatively little social stigma - were substantial. Consistent and systematic differences according to social status, though, give us confidence that the results reflect group enhancement processes and will have implications for related self-views and achievement striving.

In addition to social desirability, numerous other factors probably influence children's reported beliefs, many of which would lead to individual differences in reports of group differences. For instance, a child's beliefs regarding group differences in a specific ability are undoubtedly tempered by the child's own interest in or valuing of that domain (Eccles, Adler, Futterman, Goff, Kaczala, Meece \& Midgley, 1983). Thus, a girl for whom sports activity is a critical part of her identity would probably be less likely to report that boys are better in sports than girls (Eccles et al., 1989). The extent to which status is related to stereotype reports is probably also shaped by the extent to which those stereotypes are salient in the broader culture. In our data, both boys and girls reported substantial advantages for boys in sports whereas the status effect was less clear for music, a domain in which social stereotypes are less salient. In addition, youth may employ shifting standards of judgment depending on the comparison groups, the stakes involved and other contextual factors present when judgments are made (Biernat \& Kobrynowicz, 1997; Biernat \& Vescio, 2002).

One contextual effect that our data did not allow us to fully explore is the racial context of the school. To our knowledge, the connection between school racial composition and academic stereotypes has not been studied, but there are many studies of the relationship between interracial contact and stereotyping (Wood \& Sonleitner, 1996). Although the results were not entirely consistent, the participants tended to view Blacks most positively and Whites most negatively in predominantly Black school settings. The small and uneven cell sizes associated with these results did not allow further exploration, but this is an important area for future research.

Another limitation of our study is its cross-sectional design. Future research employing a longitudinal design would allow us to examine intra-individual change in stereotypes across this critical transition to middle school, thereby providing confirming evidence that the observed age differences are actually linked to developmental change. A longitudinal design would not only allow for an examination of the relative stability and change in stereotypes over time but would also show whether or not stereotypes are stable across domains and how changes in stereotype endorsement are associated with other changes that occur in early adolescence (e.g., identity development, academic motivation). For instance, longitudinal work would show to what extent an increasing endorsement of White academic advantage and Black sports advantage is associated with academic disengagement among Black youth.

Steele and Aronson's (1998) research (Aronson, Quinn \& Spencer, 1998) implies that negative group stereotypes negatively impact the performance of both low and high status groups. It is unclear, though, whether or not this is true for adolescents and what role, if any, does the endorsement of positive stereotypes play. In addition our study focused on group differences in stereotype endorsement. Additional research on the implications of individual differences in race and gender stereotypes on children's beliefs regarding their own competence and regarding their actual achievement striving is warranted. Of particular concern is whether or not group enhancement efforts, where members of low status groups fail to endorse widely held negative stereotypes of their 
group while strongly endorsing non-academic stereotypes that reflect positively on their social group, may result in a drop in motivation in academic areas that have real consequences for their life chances in the future. The question remains whether or not Black boys who believe that they are better than others in sports or music and are equal in academic areas will at some point stop pressing for academic achievement in favor of success in other arenas.

\section{References}

Aboud, F. (1988). Children and prejudice. Cambridge, NY: Basil Blackwell.

Alfieri, T., Ruble, D. N., \& Higgins, E. T. (1996). Gender stereotypes during adolescence: Developmental changes and the transition to junior high school. Developmental Psychology, 32, 1129-1137.

Anderman, E. M., \& Midgley, C. (1997). Changes in achievement goal orientations, perceived academic competence, and grades across the transition to middle level schools. Contemporary Educational Psychology, 22, 269-298.

Aronson, J., Quinn, D. M., \& Spencer, S. J. (1998). Stereotype threat and the academic underperformance of minorities and women. In J. K. Swim, \& C. Stangor (Eds.), Prejudice: The target's perspective (pp. 83-103). New York: Academic Press.

Augoustinos, M., \& Rosewarne, D. L. (2001). Stereotype knowledge and prejudice in children. British Journal of Developmental Psychology, 19, 143-156.

Bacharach, V. R., Baumeister, A. A., \& Furr, R. M. (2003). Racial and gender science achievement gaps in secondary education. Journal of Genetic Psychology, 164, 115-126.

Beale, F. (1970). Double jeopardy: To be Black and female. In T. Cade (Ed.), The Black woman (pp. 90-100). New York: New American Library.

Biernat, M., \& Kobrynowicz, D. (1997). Gender and race-based standards of competence: Lower minimum standards but higher ability standards for devalued groups. Journal of Personality and Social Psychology, 72, 544-557.

Biernat, M., \& Vescio, T. K. (2002). She swings, she hits, she's great, she's benched: Implications of gender-based shifting standards for judgment and behavior. Personality and Social Psychology Bulletin, 28, 66-77.

Bigler, R. S., Averhart, C. J., \& Liben, L. S. (2003). Race and the workforce: Occupational status, aspirations, and stereotyping among African American children. Developmental Psychology, 39, 572-580.

Bigler, R. S., Brown, C. S., \& Markell, M. (2001). When groups are not created equal: Effects of group status on the formation of intergroup attitudes in children. Child Development, 72 , $1151-1162$.

Bleeker, M. M., \& Jacobs, J. E. (2004). Achievement in math and science: Do mothers' beliefs matter 12 years later? Journal of Educational Psychology, 96, 97-109.

Bobo, L. (2001). Racial attitudes and relations at the close of the twentieth century. In N. J. Smelser, W. J. Wilson, \& F. Mitchell (Eds.), America becoming: Racial trends and their consequences (pp. 264-301). Washington, DC: National Academic Press.

Campbell, J. R., Hombo, C. M., \& Mazzeo, J. (2000). NAEP 1999 trends in academic progress: Three decades of student performance. Washington, DC: Department of Education, National Center for Education Statistics.

Crocker, J., \& Major, B. (1989). Social stigma and self-esteem: The self-protective properties of stigma. Psychological Review, 96, 608-630.

Csizma, K. A., Wittig, A. F., \& Schurr, K. T. (1988). Sport stereotypes and gender. Journal of Sport and Exercise Psychology, 10, 62-74.

Doyle, A. B., \& Aboud, F. (1995). A longitudinal study of White children's racial prejudice as a social-cognitive development. Merrill-Palmer Quarterly, 41, 209-228.

Eccles, J. S., Adler, T. F., Futterman, R., Goff, S. B., Kaczala, C. M., Meece, J. et al. (1983). Expectancies, values, and achievement behaviors. In J. T. Spence (Ed.), Achievement and achievement motives (pp. 75-146). San Francisco: Freeman.

Eccles, J. S., Wigfield, A., Flanagan, C., Miller, C., Reuman, D., \& Yee, D. (1989). Selfconcepts, domain values, and self-esteem: Relations and changes at early adolescence. Journal of Personality, 57, 283-310. 
Eccles, J. S., Wigfield, A., Harold, R. D., \& Blumenfeld, P. (1993). Age and gender differences in children's self and task perceptions during elementary school. Child Development, 64, 830-847.

Fagot, B. I., \& Leinbach, M. D. (1989). The young child's gender schema: Environmental input: Internal organization. Child Development, 60, 663-672.

Farmer, H. S., Wardrop, J. L., Anderson, M. Z., \& Risinger, R. (1995). Women's career choices: Focus on science, math, and technology careers. Journal of Counseling Psychology, 42, $155-170$.

Frome, P. M., \& Eccles, J. S. (1998). Parents' influence on children's achievement-related perceptions. Journal of Personality and Social Psychology, 74, 435-452.

Galambos, N. L., Almeida, D. M., \& Petersen, A. C. (1990). Masculinity, femininity, and sex roles in early adolescence: Exploring gender intensification. Child Development, 61, 1905-1914.

Graham, S., Taylor, A. Z., \& Hudley, C. (1998). Exploring achievement values among ethnic minority early adolescents. Journal of Educational Psychology, 90, 606-620.

Grant, C. D. (1985). Afro-American music: One form of ethnic identification (ERIC Document ED 268192).

Hirschfeld, L. (1996). Race in the making: Cognition, culture, and the child's construction of human kinds. Cambridge, MA: MIT Press.

Hudley, C., \& Graham, S. (2001). Stereotypes of achievement striving among early adolescents. Social Psychology of Education, 5, 201-224.

Jacobs, J. E. (1991). Influence of gender stereotypes on parent and child mathematics attitudes. Journal of Educational Psychology, 83, 518-527.

Jacobs, J. E., Lanza, S., Osgood, D. W., Eccles, J. S., \& Wigfield, A. (2002). Changes in children's self-competence and values: Gender and domain differences across grades one through twelve. Child Development, 73, 509-527.

Leahy, E., \& Guo, G. (2001). Gender differences in mathematical trajectories. Social Forces, 80, $713-732$.

Lee, E. B., \& Browne, L. A. (1995). Effects of television advertising on Black teenagers. Journal of Black Studies, 25, 523-536.

McKown, C., \& Weinstein, R. S. (2003). The development and consequences of stereotype consciousness in middle childhood. Child Development, 74, 498-515.

Miller, A. G. (1982). In the eye of the beholder: Contemporary issues in stereotyping. New York: Praeger.

National Center for Education Statistics (2002, September). Digest of education statistics. Retrieved 18 May 2004, from http://nces.ed.gov/programs/digest/d02/tables/dt255.asp.

National Science Foundation (2000). Women, minorities, and persons with disabilities in science and engineering (NSF Rep. No. 00-327). Arlington, VA: National Science Foundation.

Nesdale, D., \& Flesser, D. (2001). Social identity and the development of children's group attitudes. Child Development, 72, 506-517.

Parsons, J. E., Adler, T. F., \& Kaczala, C. M. (1982). Socialization of achievement attitudes and beliefs: Parental influences. Child Development, 53, 310-321.

Ruble, D. F., \& Martin, C. L. (1998). Gender development. In N. Eisenberg (Ed.), Handbook of child psychology, Vol. 3: Social, emotional, and personality development (pp. 933-1016). New York: Wiley.

Ruble, T. L., Cohen, R., \& Ruble, D. N. (2001). Sex stereotypes. American Behavioral Scientist, 27, 339-356.

Sailes, G. A. (1991). The myth of Black sports supremacy. Journal of Black Studies, 21, 480-487.

Sidanius, J., \& Pratto, F. (1999). Social dominance: An intergroup theory of hierarchy and oppression. New York: Cambridge University Press.

Sidanius, J., \& Veniegas, R. C. (2000). Gender and race discrimination: The interactive nature of disadvantage. In S. Oskamp (Ed.), Reducing prejudice and discrimination (pp. 47-69). Mahwah, NJ: Erlbaum.

Signorella, M. L., Bigler, R. S., \& Liben, L. S. (1993). Developmental differences in children's gender schemata: A meta-analytic review. Developmental Review, 13, 147-183.

Steele, C. (1997). A threat in the air: How stereotypes shape the intellectual identities and performance of women and Blacks. American Psychologist, 52, 613-629. 
Steele, C. M., \& Aronson, J. (1998). Stereotype threat and the test performance of academically successful African-Americans. In C. Jencks \& M. Phillips (Eds.), The Black-White test score gap (pp. 401-427). Washington, DC: Brookings Institution Press.

Swim, J. K., \& Stangor, C. (1998). Prejudice: The target's perspective. New York: Academic Press.

Tajfel, H. (1970). Experiments in intergroup discrimination. Scientific American, 233, 96-102.

Tajfel, H., \& Billig, M. G. (1974). Familiarity and categorization in intergroup behavior. Journal of Experimental Social Psychology, 10, 159-170.

Tiedemann, J. (2000). Parents' gender stereotypes and teachers' beliefs as predictors of children's concept of their mathematical ability in elementary school. Journal of Educational Psychology, 92, 144-151.

Weinraub, M., Clemens, L. P., Sockloff, A., Ethridge, R., Gracely, E., \& Myers, B. (1984). The development of sex role stereotypes in the third year: Relationships to gender labeling, gender identity, sex-typed toy preferences, and family characteristics. Child Development, 55 , 1493-1503.

Wigfield, A., \& Eccles, J. S. (1994). Children's competence beliefs, achievement values, and general self-esteem: Change across elementary and middle school. Journal of Early Adolescence, 14, 107-138.

Wigfield, A., Eccles, J. S., Harold, R. D., Blumenfeld, P. C., Arbreton, A., Freedman-Doan, C. R. et al. (1997). Change in children's competence beliefs and subjective task values across the elementary school years: A 3-year study. Journal of Educational Psychology, 89, 451-469.

Wood, P. B., \& Sonleitner, N. (1996). The effect of childhood interracial contact on adult antiblack prejudice. International Journal of Intercultural Relations, 20, 1-17.

\section{Acknowledgments}

Rashmita Mistry is currently at the University of California, Los Angeles. This research was supported by the National Institute of Mental Health grant P50 MH52429 to Robert Cairns. We are grateful to Ryan Kinlaw, Julie Moore, Taniesha Woods, Patricia Johnson, Crystal Barksdale, Tiffini Billingsly, T'Fani Bose, Correy Campbell, Achankeng Fonge, Mayowa Obasaju and Kimberly Taylor for their assistance with data collection. 